\title{
New and improved training programmes at the Institute of Advanced Legal Studies Library
}

\author{
by David Gee \\ Deputy Librarian \& Academic Services Manager \\ Institute of Advanced Legal Studies \\ and Gerry Power \\ Access Librarian \\ Institute of Advanced Legal Studies
}

Since the restructuring of the Reader Services department (now the Academic Services department) of IALS Library in 2000 and the subsequent investment in additional staff capacity, IALS Library has consciously sought to develop and improve both the public training programmes delivered to researchers and the in-house training programmes provided for library staff. This article seeks to explain the key changes that took place and to describe the resulting expansion in both types of training programmes. The department was fortunate in being able to appoint Gillian Sands as LLM Services Librarian in January 2001 in a move from the Library's Book Acquisitions section and Gillian quickly became an integral part of the Reader Services team. Happily Gillian's invaluable years at IALS coincided with an exciting and rewarding period of expansion and innovation in the library. As in so many other areas of her work, she bought sensible practical ideas, much bubbly enthusiasm, and a great deal of hard work to help the team make these improvements to services a success.

\section{Restructuring and new priorities}

In 2000, with the retirement of Jill Newell MBE, the IALS Librarian, Jules Winterton, took the opportunity to restructure the IALS Library Reader Services department and create a new post of Reader Services Manager. This post was needed to bring together all the existing expertise and talent within the department to create a coherent team and to take forward and develop new service initiatives. One of the existing members of IALS Library staff, David Gee, was recruited to this new post. The new Reader Services Manager was keen to create a new team ethos as quickly as possible. He recognised that improving the physical location of desks and people in the staff area would not only ensure that the team members actually sat much closer together and could therefore communicate more easily than previously, but that this physical move would help to foster a more inclusive team atmosphere. David also inaugurated regular team meetings and actively encouraged staff to discuss new service ideas and contribute improvements to existing services.

We were particularly keen to develop and improve the existing public and inhouse training programmes delivered by library staff. From visiting other large research libraries in the USA such as the law libraries at Columbia, New York and Yale Universities, the Reader Services Manager was convinced that the law librarian's role was changing and that IALS library staff could and should 
adapt and develop. ${ }^{1}$ Whereas previously reference staff had spent most of their time answering reference enquiries and undertaking bibliographic research projects, there was a clear indication that we needed to expand both our skills training role and our role in creating value-added web resources. IALS reference staff had always provided excellent skills training sessions in electronic resources such as LexisNexis and Westlaw and had created many published legal research guides, but by necessity these were minor roles compared to the daily need to answer quickly and effectively the seemingly never-ending stream of legal reference enquiries. However due to the exponential growth of web legal resources and the development of intuitive and sophisticated web gateways, it was becoming likely that the number of reference enquiries would soon start to plateau in academic libraries generally and it was crucial that reference librarians started to expand the two other key roles. With the appointment of the new Reader Services Manager with his new priorities and a determination to develop an inclusive team, these two minor roles started to develop and grow in importance.

\section{Increased staff capacity}

The other important factor in enabling IALS Library to improve and expand its training provision was the investment in new staff. The department already benefited hugely from the extensive reference experience and much-valued training expertise of the Senior Reference Librarian, Paul Norman, and was very lucky to recruit two young and enthusiastic staff.

Firstly, Gillian Sands was appointed as LLM Services Librarian in January 2001. Gillian's main responsibility was to deliver proactive library support services to University of London LLM students. Her duties included providing a readers' advisory service to students, developing a close liaison with University of London law lecturers and identifying books for purchase from LLM reading lists. She also participated in the selection of subscription material at acquisitions meetings, assisted the Librarian with the assessment of new University of London LLM course proposals and updated the web pages specifically focussed at University of London LLM students. Gillian was deservedly promoted to Assistant Librarian in December 2002 and was given additional reader services responsibilities.

Secondly, using RSLP funding granted in recognition of the large number of external users who use IALS Library, Gerry Power was appointed as the first IALS Access Librarian in January 2001. Gerry's duties centre on supporting and promoting the use of the library by academic researchers throughout the UK both in person and at a distance. Amongst many new and imaginative outreach initiatives, in 2002 he created the very useful UK Current Legal Research Topics Database available on the IALS website at http://ials.sas.ac.uk/library/clrt/clrt.htm. The purpose of this free database is to provide a listing of legal research currently being undertaken in British law schools at MPhil and PhD level. The database is most useful for postgraduate students who are undertaking, or thinking of undertaking, a law research degree. Gerry has also created a new colour brochure and colour bookmarks which have been sent to law librarians and law faculties across the UK, and 
organised very successful "roadshows" at the law faculties of other universities (e.g. Cardiff, Strathclyde, De Montfort and Exeter) where IALS Library staff have given presentations to lecturers and researchers about our collaborative electronic projects and services. Currently Gerry is developing an updated "news" column for academic users across the UK on the library website at http://ials.sas.ac.uk/library/aservice/aservice.htm.

From the start, David Gee was keen to ensure that all his staff, including our highly experienced Senior Library Assistant, Katherine Read, were able to participate in the creation, promotion and facilitating of the public training programmes. By deliberately developing the training skills and database knowledge of all the members of the Reader Services team, he recognised that not only would the library be able to expand and extend the number of training sessions offered to researchers, but that these trained staff would be able, in time, to "cascade" these key skills down to other library staff and thereby improve the general service levels offered to researchers on the Enquiry Desk. The discussions leading to the creation of new public programmes also helped to motivate staff with new and exciting challenges and to encourage a supportive team atmosphere.

\section{Improved public training programmes delivered to researchers}

Over the past five years all the team have worked very hard in developing new training, learning and database skills and have achieved an enormous amount. Using information gleaned from feedback forms from previous sessions, we have continually revised and modified our public training programmes to try to meet the changing needs of the researchers. We were also lucky that during this period Gerry Power studied successfully for a parttime postgraduate teaching qualification at Birkbeck College in the University of London. As a result of his new theoretical knowledge of how students learn and how best to teach them and his growing practical teaching skills, we were able to refine our training programmes still further.

\section{From product profiles to key skills}

When we began as a team to offer electronic sessions in 2001, product profiles and online demonstrations were the mainstay of our talks. We regularly featured prominent services like LexisNexis, Westlaw UK and Heinon-line. Lots of background information on each product was given, as were handouts illustrated with search examples and screen shots. With time, and with lots of feedback from our learners, we developed a more generic approach to online legal research: we demonstrated searching, navigating, getting help files, selecting databases, trouble-shooting, distinguishing between summaries and full text, printing and saving, using taxonomies - all across a range of the prominent legal databases. We answered many questions from students, but individual support is difficult in an online demonstration to 20 students. So in 2003 we tentatively started "hands-on" workshops for groups of 10 students in which a brief demonstration was followed by a number of search and navigation exercises, one student per PC. These proved so popular that "hands-on" sessions are now the mainstay 
of our training programme. We encourage students to practice their use of different databases, to help their research now and for the future. The "handson" sessions now offer plenty of opportunity to support students individually.

The curriculum content of the University of London LLM programme alone is very diverse, with over 180 courses, so we try to reflect this diversity by including search examples from across the spectrum of legal research, during our sessions. And as we specialise in law, we encourage our doctoral and masters students to look for help elsewhere if they don't find the material they need at IALS. Helping them to cultivate an interdisciplinary approach in their research can introduce them to other useful gateways, such as the Resource Discovery Network, http://www.rdn.ac.uk/ or to subject specialists in their college library. For instance, in one of our skills sessions for new $\mathrm{PhD}$ students, a student asked about energy policies in Eastern and Central Europe, post-Chernobyl. She said she had exhausted the legal literature on this, and not found much, but we were able to encourage her to try the RDN as a starting point, which got her started with OECD energy reports. She asked her college library for help, too.

IALS Library is now in the position in the autumn and spring terms to offer researchers and postgraduate students twice-weekly two-hour "hands-on" training workshops comparing both the LexisNexis and Westlaw UK databases. During the early part of the autumn term we also offer general introductions to our own wide-ranging electronic legal resources. These include help with accessing and using databases such as Justis.com, Heinon-line, Butterworths Direct, CaseBase (Australian materials), CaseTrack (UK cases) and the United Nations Treaty Collection. Training is also given in how to access (both onsite and remotely) our growing number of full-text electronic journals and use our indexing services such as the Index to Legal Periodicals, Index to Foreign Periodicals and Legal Journals Index. In addition we offer regular thematic sessions on finding electronic sources of legislation, law reports and journal articles. Later in the autumn term and during the spring term we offer regular training sessions on using electronic sources of public international law, electronic sources of EU law, electronic sources of human rights law, and finding free Internet sources of law.

These public sessions are advertised in LLM student induction packs, by posters in the library and on the homepage of the library website. They are also highlighted during IALS library tours and at the college library induction sessions held at UCL, LSE, SOAS, King's College London and Queen Mary College London at the beginning of the academic year. The "hands-on" training workshops are facilitated in our Electronic Information Unit on the $4^{\text {th }}$ floor of the Library. As attendance is entirely voluntary, we have deliberately offered a variety of time-slots for our training sessions in order to give researchers and students the widest opportunity to attend. We have found that one of the most popular times is over the lunch-hour when researchers and students are encouraged to bring their lunch with them to eat during the session. 
Reassuringly, we have always had very good feedback returns for our public training programmes as well as very high scores in successive annual Reader Satisfaction Surveys (e.g. 88.9\% satisfaction in the most recent 2005 Reader Survey). It is clear that researchers and postgraduate students have enjoyed and benefited from the sessions and now view our annual programme of training sessions as a major value-added library service.

\section{Other benefits of the improved training programmes}

As a result of their involvement in facilitating the public training sessions, our more experienced and skilled Reader Services staff are now able to give improved one-to-one tailored assistance to individual researchers as and when they need help in using particular databases or in deciding their research strategies. They are also on hand to "cascade" their skills and knowledge to library colleagues and this has much improved the overall level of service provided by staff at the public enquiry desk and on the telephone reference desk.

Members of the Reader Services team have also been invited to teach sessions on the Institute's Introduction to Legal Research Methods Course in January every year. This intensive two-week course provides research skills training for newly registered MPhil and $\mathrm{PhD}$ law students across the University of London and University of Westminster. Participants get an opportunity to review examples of legislation, case reports, articles and finding tools and look at resources for different jurisdictions, international law and subject areas of law. They also consider issues of quality and relevance when using free legal materials on the web. In addition members of the team have organised and facilitated several new half-day and full-day courses on using legal resources for training organisations such as CPD25 and BIALL.

We have also recently started to invite law lecturers from the University of London colleges to small training seminars which concentrate on explaining how researchers can easily access our electronic resources offsite at college or home as well as onsite in the library. These seminars also give participants a greater understanding of how IALS Library web databases and web gateways can help them in the course of their work.

As one skill leads to another we have found that the acquired database skills and bibliographic knowledge developed from improving the public training programmes have also enabled the Reader Services team to develop additional value-added services on the IALS Library website which are freely available for all UK law librarians and law researchers to use. Firstly the team have completely updated the existing country research guides to the legal literature and electronic resources in Belgium, France, Germany, Ireland, Italy, Luxembourg, Netherlands and Spain, and written new web research guides on UK, USA and public international law legal resources at http://ials.sas.ac.uk/library/guides/research guides.htm. Secondly a series of IALS Quick Reference Guides on how to find statutes and cases from France, Germany and Italy using the internet and IALS printed resources have been created on our library website, and thirdly, the team - particularly Katherine, 
Gillian and the department's Graduate Trainee worked together to develop the library's range of popular subject guides to legal resources, including guides with embedded web links on company, commercial and insolvency law, environmental law, European Union law, family law, human rights law, IT and telecommunications law and intellectual property law at http://ials.sas.ac.uk/library/guides/subject guides.htm. Many of these guides also feature in the Lawpaths Resources Database. ${ }^{2}$ Recently, with many colleagues from libraries in the central University, we have contributed some content to the Library Research Skills Tutorial at: http://www.ulrls.lon.ac.uk/tutorial. This free online tutorial aims to help students develop transferable skills in their research: planning research, using different libraries, using a range of search tools and resources, and compiling bibliographies. Finally, when time allows, we contribute records to the Law Gateway section of the prestigious national SOSIG (Social Science Information Gateway) at http://www.sosig.ac.uk. Since 1999 work to develop and edit the SOSIG Law Gateway has been led by Steven Whittle at IALS Library and Sue Pettit at the University of Bristol Law Library.

\section{Future initiatives}

The Reader Services section was re-named the Academic Services department in 2004 and David Gee was promoted to the post of Deputy Librarian \& Academic Services Manager in 2005. Mindful that students learn in different ways, in the future, we are hoping to develop a range of free selfpaced interactive web tutorials for our key electronic databases and indexing tools. Ideally, we would also like to explore the possibilities of contributing teaching content to an existing University of London LLM course. We are also thinking of possible ways of increasing the size of the Electronic Information Unit on the $4^{\text {th }}$ floor in order to accommodate more researchers at our workshops. However, lack of space is a real problem at the Institute at present and we may need to wait until the IALS building is extended and refurbished before we can physically expand the size of the training facilities.

\section{Improved in-house training programmes provided for library staff}

Over the past five years the Academic Services Manager has also developed and improved the in-house training programmes provided for library staff. As in other academic research libraries we provide all new staff with a number of planned induction training sessions, detailed training in Issue \& Enquiry Desk procedures and comprehensive on-going sectional training. This is supplemented by extensive IT training and, where appropriate, funding for attendance at external training courses and conferences organised by such training organisations as Cilip, CPD25, Aslib, BIALL, IALL, CLIG and the UK Serials Group. We offer a CILIP-approved Route "A" Chartership Programme, encourage post-library qualification staff to register as Cilip chartership candidates and provide chartership supervision for our own candidates and for library staff based at other Institute Libraries within the School of Advanced Study. The Academic Services Manager and the other two departmental managers at the Institute Library (the Information Resources Manager and the Information Systems Manager) form the Library Staff Training Needs Group 
and meet regularly to review the training provided for new library staff. They also plan the fair and appropriate allocation of the training budget to encourage continuous professional development among more experienced library staff. Library staff use evaluation forms to write critical assessments of the benefits or otherwise of the training courses and conferences that they attend. These evaluations help us gauge the value of these courses for future colleagues. Regular feedback sessions on the usefulness of the in-house training programmes are also organised. The Institute's annual appraisal process also identifies staff development needs.

The Academic Services Manager also organises the annual wednesday afternoon in-house training programme for new library staff. This series of about twenty wednesday afternoon training sessions runs from November to August each year and amounts to a significant investment by IALS Library in the training of new law librarians. The programme combines practical workshops on legal bibliography and other law librarianship training with useful visits to other types of law library for comparative purposes. For example we provide practical workshop introductions to UK law sources, EU law sources, US law sources, Commonwealth law sources and public international law sources. The comparative merits of paper and electronic sources are fully covered during these "hands-on" sessions facilitated by senior IALS library staff. There are also training sessions on cataloguing and classifying legal materials, the Dreamweaver web-authoring software, using the SOSIG Law Gateway, using the BAILII service (at http://www.bailii.org), the IALS archives, the role and duties of the LLM Services Librarian and the role and duties of the Computing Services Librarian. During the summer months the new staff also get an opportunity to visit the British Library, Lincoln's Inn Library, the Law Society Library, LSE Library and Norton Rose (Solicitors) Library.

\section{Law librarians from other libraries attend IALS training sessions}

Although the extensive wednesday afternoon in-house training programme is organised primarily for the benefit of our own staff and we are keen to keep the numbers attending to a maximum of about twelve in order to preserve the "workshop" element, we have been very keen to invite new law librarians from other libraries to attend some of these sessions. IALS Library has always taken the view that providing law librarianship training is a key part of its national role. As a result, over the years we have been pleased to welcome new law librarians from the British Library, School of Oriental African Studies Library, Middlesex University Library, Surrey University Library, Senate House Library, Lincoln's Inn Library, Gray's Inn Library, Inner Temple Library, Middle Temple Library and the Foreign and Commonwealth Office Legal Library - all attending IALS Library training sessions free of charge.

\section{Graduate Trainee programme}

As well as including any new IALS library staff and other new law librarians from other law libraries in the wednesday afternoon in-house training programme, we always make sectional time to enable all four of our one-year 
Graduate Trainees to attend all the sessions. Our four Graduate Trainees are recruited each year via the national SCONUL / Cilip pre-library school recruitment scheme. ${ }^{3}$ This scheme attracts excellent new graduates to the Institute Library who bring many new ideas and a great deal of enthusiasm. In return, as well as getting a valuable opportunity to attend our public and inhouse training courses, they are trained to work on the Issue \& Enquiry Desk and are deliberately moved from section to section every three months to ensure that they receive in-depth training in all the main activities of the library. At the end of their varied traineeship year the Trainees are therefore in a position to recognise the many links between the different library sections and to appreciate how the library fits together and functions as a whole. After leaving us and gaining a post-graduate information qualification at library school, these law librarians often go on to work in academic law libraries, law firm libraries and other specialist law libraries across the UK. Over the years, because of our Graduate Trainee programme, many tens of law librarians have gained their first professional experience at IALS Library. ${ }^{4}$

\section{Conclusions}

Over the past five years IALS Library has invested a great deal of staff time and resources in improving the public training programmes offered to researchers and in developing the in-house training programmes provided for library staff. The success of these key service initiatives is the direct result of the creative input, team working and hard work of all the Academic Services staff.

\section{References}

1. Gee, David - A comparison of four premier academic law libraries in the United States and United Kingdom: the findings of a valuable international placement. International Journal of Legal Information, vol.31, no.3, Winter 2003. pp.520-533.

2. The Lawpaths Project website is available at: http://library.kent.ac.uk/library/lawpaths/default.htm. The Project Partners are the University of Kent, IALS, UKCLE, the University of Bristol and the University of Cardiff.

3. More information on the SCONUL / Cilip Graduate Trainee scheme is available on the Cilip website at: http://www.cilip.org.uk/qualifications.

4. More information about the IALS Library Graduate Trainee programme is available at http://ials.sas.ac.uk/library/trainees.htm. 